\title{
LA INMATRICULACIÓN DE LA MEZQUITA- CATEDRAL DE CÓRDOBA: TUTELA DEL PATRIMONIO Y RELEVANCIA CONSTITUCIONAL
}

\author{
Miguel Agudo Zamora
}

doi: 10.18543/ed-63(2)-2015pp15-45

\begin{abstract}
Sumario: 1. InTROdUCCiÓN. 2. LA INMATRICUlación DE LA MEZQUITA-CATEDRAL POR PARTE DEl OBISPAdo DE CóRdoba USANDO LA POTESTAD DEL ARTíCULO 206 DE LA LEY HiPOTECARIA. 3. LA POSIBLE INCOnstitucionalidad Del artículo 206 LH. 3.1. Por infracción del principio de aconfesionalidad del Estado. 3.2. Por infracción del principio de igualdad. 3.3. La STEDH «Sociedad Anónima del Ucieza contra España». 4. LA TUTELA DEL PATRIMONIO HISTÓRICO Y CULTURAL POR LA COMUNIDAD AUTÓNOMA DE ANDALUCÍA. 5. LA IMPUGNACIÓN DEL ARTÍCULO 206 LH A TRAVÉS DE UNA CUESTIÓN DE CONSTITUCIONALiDAD. 6. CONCLUSIONES. 7. BIBLIOGRAFÍA.
\end{abstract}

\section{INTRODUCCIÓN}

La polémica suscitada como consecuencia de la inmatriculación de la Mezquita-Catedral de Córdoba a nombre de la Iglesia Católica usando la potestad atribuida por el artículo 206 de la Ley Hipotecaria ha tenido gran repercusión social. Pero, más allá de ésta, ha servido como ocasión oportuna para reflexionar sobre la relevancia jurídico-constitucional de esta normativa y sobre el deber de tutela del patrimonio por parte de la Administración Pública.

La razón de ser de esta justificada repercusión parte de una modificación normativa efectuada en el año 1998, que permitió a la Iglesia Católica inscribir lugares de culto y otras propiedades que no estuvieran registradas con una mera certificación expedida por el Obispado. La consecuencia de esta refor- 
ma fue una intensa actividad registral por parte de las Diócesis. En este proceso, la Iglesia registró a su nombre más de 4.500 propiedades, según fuentes fiables cercanas a los registros de la propiedad, aunque no existe realmente ningún listado público en el que se encuentren referidas todas las inscripciones registrales llevadas a cabo por la Iglesia.

En relación a la Mezquita-Catedral, a finales de 2013 se creó una plataforma cívica para tratar de frenar este proceso. En un manifiesto que ha recibido más de 200.000 firmas la Plataforma Mezquita-Catedral de Córdoba: patrimonio de todos exige la titularidad y gestión pública del monumento. La plataforma ha recibido el respaldo de numerosos intelectuales. Entre ellos, Federico Mayor Zaragoza, que fuera durante doce años director general de la Unesco -entre 1987 y 1999- y actualmente presidente de la Fundación Cultura de Paz, quien advirtió incluso de la posibilidad de que el monumento perdiera la titularidad de Patrimonio Mundial que le otorgó la Unesco en 1984. Incluso la polémica ha traspasado la dimensión local y nacional, llegando a convertirse en un asunto de referencia internacional ${ }^{1}$.

En este trabajo, partiendo del caso de la Mezquita-Catedral se exponen sucintamente los argumentos en los que basar una posible inconstitucionalidad del artículo 206 de la Ley Hipotecaria, referidos a la violación de los principios constitucionales de aconfesionalidad del Estado y de igualdad, con referencias a la Sentencia del Tribunal Europeo de Derechos Humanos «Sociedad Anónima del Ucieza contra España», que tiene una relevancia específica para el objeto de nuestro estudio.

Finalmente se analiza el deber de tutela del patrimonio histórico y cultural de la Comunidad Autónoma de Andalucía y el posible uso de la cuestión de constitucionalidad como vía de actuación de la Junta de Andalucía en relación a la inscripción registral de la Mezquita-Catedral.

Debemos, antes de seguir avanzando en nuestro estudio, reseñar que este artículo 206 de la Ley Hipotecaria ha sido derogado por la Ley 13/2015, de 24 de junio, de Reforma de la Ley Hipotecaria aprobada por Decreto de 8 de febrero de 1946 y del texto refundido de la Ley de Catastro Inmobiliario, aprobado por Real Decreto Legislativo 1/2004, de 5 de marzo ${ }^{2}$. Lo que no

1 Valga como referencia, entre otras muchas, el estudio que le dedica la revista Foreign Policy <http://foreignpolicy.com/2015/04/10/the-reconquista-of-the-mosque-of-cordoba-spain-catholic-church-islam $>$.

${ }^{2}$ El nuevo artículo 206 LH señala: «1. Las Administraciones Públicas y las entidades de Derecho público con personalidad jurídica propia vinculadas o dependientes de cualquiera de aquéllas podrán inmatricular los bienes de su titularidad, mediante la aportación de su título escrito de dominio, cuando dispongan de él, junto con certificación administrativa librada, previo informe favorable de sus servicios jurídicos, por el funcionario a cuyo cargo se encuentre la administración de los mismos, acreditativa del acto, negocio o modo de su adquisición y fecha del acuerdo del órgano competente para su inclusión en el inventario corres- 
obsta para que, de cara a una eventual impugnación de la inmatriculación de la Mezquita-Catedral, a través del ejercicio de la acción de la cuestión de constitucionalidad, se puedan alegar las vulneraciones de principios constitucionales que se señalan en este trabajo.

\section{LA INMATRICULACIÓN DE LA MEZQUITA-CATEDRAL POR PARTE DEL OBISPADO DE CÓRDOBA USANDO LA POTESTAD DEL ARTÍCULO 206 DE LA LEY HIPOTECARIA}

En primer lugar, debemos señalar que este trabajo, partiendo de un somero análisis de los argumentos esgrimidos acerca de la titularidad de la Mezquita-Catedral, se centrará fundamentalmente en determinados aspectos relacionados con la inmatriculación de la misma que, en nuestra opinión, gozan

pondiente o, caso de no existir, fecha del acuerdo de aprobación de la última actualización del inventario de la que resulte la inclusión del inmueble objeto de la certificación con indicación de la referencia o indicador que tenga asignado en el mismo, así como de su descripción, naturaleza patrimonial o demanial y su destino en el primer caso o su eventual afectación, adscripción o reserva, en el segundo. Asimismo, las entidades referidas deberán aportar certificación catastral descriptiva y gráfica de la parcela o parcelas catastrales, que se corresponda con la descripción literaria y la delimitación geográfica de la finca cuya inmatriculación se solicita en la forma establecida en la letra b) del artículo 9. Solo en caso de que la finca careciese de certificación catastral descriptiva y gráfica, podrá aportarse una representación gráfica georreferenciada alternativa, la cual deberá corresponderse con la descripción literaria realizada y respetar la delimitación de los colindantes catastrales y registrales. A la representación gráfica alternativa deberá acompañarse informe del Catastro. 2. En todo caso, será preciso que el Registrador compruebe la falta de previa inmatriculación de todo o parte del inmueble. Si advirtiera la existencia de fincas inscritas coincidentes en todo o en parte, denegará la inmatriculación solicitada, previa expedición de certificación de las referidas fincas, que remitirá al organismo interesado junto con la nota de calificación. 3. Practicada la inmatriculación, el Registrador expedirá el edicto a que se refiere la regla séptima del apartado 1 del artículo 203 con el mismo régimen en ella previsto, incluido el sistema de alertas. 4. Junto al procedimiento registral ordinario, cuando se trate de fincas propiedad de alguna de las entidades referidas en el apartado 1, podrá obtenerse la reanudación del tracto sucesivo interrumpido a través de certificación administrativa, expedida con los requisitos señalados en el presente artículo, que ponga fin al procedimiento regulado en el apartado 3 del artículo 37 de la Ley 33/2003, de 3 de noviembre, de Patrimonio de las Administraciones Públicas. 5. Además de ello, mediante certificación administrativa del acto en que así se disponga, podrán practicarse, en los bienes de titularidad de las Administraciones Públicas y de las entidades de Derecho público a que refiere el apartado 1 de este artículo, operaciones registrales de agrupación, división, agregación, segregación, declaración de obra nueva, división horizontal, constitución de conjuntos inmobiliarios, rectificación descriptiva o cancelación, siempre que tales actos no afecten a terceros que no hubieran sido citados en el expediente, se cumplan los requisitos establecidos por la legislación sectorial y se aporte la representación gráfica catastral de la finca o representación alternativa, en los términos previstos en el artículo 10.» 
de una cierta relevancia constitucional, así como sobre el deber de tutela del patrimonio histórico por parte de la Junta de Andalucía.

A título exclusivamente introductorio, pues, indicaremos los principales argumentos que se invocan para defender la propiedad privada o pública de la Mezquita-Catedral. En todo caso, con carácter aún más previo, se debe aclarar que a lo largo de este trabajo se mencionará a la Mezquita-Catedral con ese nombre, puesto que es el que recoge el Catálogo General del Patrimonio Histórico Andaluz realizado por la Consejería de Cultura de la Junta de Andalucía ${ }^{3}$.

NiETO CuMPLIDO ${ }^{4}$ cita varios documentos en los que se apunta que la Iglesia es la legítima propietaria del edificio, documentos como la Primera Crónica General de España, de Alfonso X el Sabio (siglo XIII); la Historia De rebús Hispaniae del arzobispo de Toledo, Rodrigo Ximénez de Rada (siglo XIII); y una bula concedida por el papa Gregorio IX al rey Fernando III, en los que se apunta que la Iglesia es la legítima propietaria del edificio. También re refiere al testimonio del rey Felipe IV (1659), en el que agradece al obispo «como dueño lexítimo» del templo el poder trasladar la nueva Capilla Real.

Junto a ello, un argumento reiteradamente referido es el relativo a la usucapión atendiendo a la posesión pacífica, continua y pública de la MezquitaCatedral por parte de la Iglesia Católica.

Con este fundamento, el 2 de marzo de 2006, el Cabildo Catedralicio de Córdoba inmatriculó (es decir, inscribió por primera vez en el Registro de la

${ }^{3}$ Esta es la ficha que aparece en dicho Catálogo:

Mezquita Catedral

Denominación del bien: Mezquita Catedral

Otra denominación: Antigua Mezquita Aljama, Antigua Mezquita Mayor-Iglesia Catedral de la Asunción de Nuestra Señora, Iglesia Catedral de la Asunción de Nuestra Señora, Mezquita de Córdoba

Provincia: CORDOBA

Municipio: CORDOBA

Régimen de protección: B.I.C

Estado administrativo: Inscrito

Fecha de disposición: 21/11/1882

Tipo de patrimonio: Inmueble

Tipología jurídica: Monumento

Boletín oficial: Gaceta del 27 de noviembre de 1882

(Consultado el 7-11-2014 a las 18.00 hs. en: <http://www.juntadeandalucia.es/culturaydeporte/web/areas/bbcc/catalogo? tipologia \&sort $=a \&$ sortBy $=p \&$ inicio $=$ false $\&$ t $p=1$ \&estado_administrativo $=$ Inscrito\&mun $=6178 \& p r=14 \&$ page $=6>$ )

${ }^{4}$ Nieto Cumplido, M., La Catedral de Córdoba, Cajasur Publicaciones, Córdoba, 1998, pág. 319.Esta es una de las obras más completas realizadas sobre la Mezquita-Catedral, escrita por este doctor en Historia Eclesiástica y canónigo archivero de la catedral cordobesa. Ver también Baena Alcantara, M.D., La Mezquita-Catedral de Córdoba, Francisco Baena, 1986. 
Propiedad) la Mezquita-Catedral con el nombre de «Santa Iglesia Catedral de Córdoba».

Lo hizo con el siguiente texto:

«URBANA.-SANTA IGLESIA CATEDRAL DE CORDOBA, situada en la calle Cardenal Herrero número uno, de Córdoba; comprende una extensión superficial de veinte mil trescientos noventa y seis metros cuadrados, con igual superficie construida, según se desprende todo ello de la certificación descriptiva y grafica emitida por la Gerencia Territorial del Catastro a través del Instituto de Cooperación de la Hacienda Local, el día 21 de febrero de 2.006 que se acompaña. Linda, visto desde su entrada, por la derecha, con la calle Torrijos; por la izquierda, con la calle Magistral González Francés; por el fondo, con la calle Corregidor Luis de la Cerda; y por su frente, con la calle Cardenal Herrero. Antigua Basílica visigoda de San Vicente y mezquita. Reconquistada la ciudad por Fernando III el Santo, el monarca dispuso que en la festividad de los Santos Apóstoles Pedro y Pablo del año 1.236 fuera dedicada a Santa María Madre de Dios y consagrada aquel mismo día por el Obispo de Osma Don Juan Domínguez, en ausencia del Arzobispo de Toledo Don Rodrigo Jiménez de Rada, asistido por los Obispos de Cuenca, Baeza, Plasencia y Coria. La ceremonia de trazar con el báculo sobre una faja de ceniza extendida en el pavimento en forma de cruz diagonal las letras de los alfabetos griego y latino fue la expresión litúrgica y canónica de la toma de posesión por parte de la Iglesia. Todo el edificio quedó convertido en templo cristiano, pero no adquirió el carácter de Catedral hasta la elección del primer Obispo, Don Lope de Fitero, poco antes del mes de noviembre de 1.238, y de su consagración episcopal en un día de los primeros meses del año siguiente. La Catedral fue declarada monumento nacional en 1.882 y monumento Patrimonio de la Humanidad en 1.984. El inmueble está destinado al culto católico.»

En sentido contrario, se argumenta que la Mezquita-Catedral no es susceptible de propiedad privada debido a que los bienes de dominio público no se adquieren por la posesión en el tiempo dado que este edificio siempre perteneció al Estado, aunque no exista una declaración expresa que así lo confirme, de la misma manera que tampoco existe documento privado que lo niegue.

La titularidad de la propiedad de la Mezquita se otorga por conquista a la monarquía castellana. Con base en este hecho, se argumenta que la Mezquita-Catedral nunca ha dejado de ser de titularidad civil y pública, sin perjuicio de que la Iglesia Católica haya sido su usuaria.

Para RODRÍGUEZ RAMOS ${ }^{5}$, «la jerarquía católica, ante la contradicción que supone argumentar la usucapión de un bien inmueble que admite perteneció

${ }^{5}$ Rodríguez Ramos, A.M., «Nulidad de la inmatriculación de la Mezquita-Catedral», (consultado el 26-11-2014 a las 19.00 hs en <http://laicismo.org/detalle.php? tg=1 $569 \& p g=1 \& p k=32693 \# p p a l>$ ) 
por conquista a la monarquía castellana, alega una posible donación por parte de Fernando III. No existe documento que así lo acredite porque de haber existido con total seguridad se hubiera aportado en el Registro de la Propiedad, donde por el contrario sí reconocen la titularidad de la corona de Castilla. En consecuencia, el sometimiento jurídico a su Derecho y en particular a las Siete Partidas de Alfonso X. Posteriormente, fue Carlos I, mediante Real Cédula de 7 septiembre 1555, quien dejó claro que «cuando ocurriese duda sobre Las Partidas se acudirá al comentario de Gregorio López».

En la Partida Quinta, Título IV de las donaciones y Ley IX, se establece que el «Emperador o rey, puede fazer donación con carta o sin carta, e valdrá». Sin embargo, Gregorio López en la Magna Glosa aclara que «en las donaciones reales, requiérese escritura si exceden de 500 sólidos» (moneda romana que equivalía a 25 denarios de oro). Una garantía mínima para evitar el expolio sin pruebas del patrimonio real.

En consecuencia, continúa argumentando este autor, si no existe documento en que conste la donación expresa por parte de la Corona al Cabildo (no el mero reconocimiento de una titularidad habitualmente confundida con el uso), la Mezquita-Catedral pertenece al Estado y no puede ser usucapida.

Como argumentos adicionales, que inciden en el mismo sentido, se recuerda que cuando el Cabildo eclesiástico quiso destruir las arcadas centrales de la Mezquita para construir la Catedral, se opuso el Cabildo Municipal, incluso con pena de muerte para quien se atreviera a tocar los $\operatorname{arcos}^{6}$. La sentencia real de Carlos V permitió la construcción, aunque después se arrepintiera en su visita de 1526: "Yo no sabía lo que era esto; pues no hubiera permitido que se llegase a lo antiguo; porque hacéis lo que puede haber en otras partes y habéis deshecho lo que era singular en el mundo»?

Para RodRíguez RAMOs, esto demuestra que no era competencia del Obispo decidir en exclusiva sobre el monumento, pues la decisión final era

${ }^{6}$ Así consta en las Actas Capitulares de 1520 y en una Real Provisión fechada en Loja el 14 de julio de 1523, declarando la Chancillería que el Provisor de Córdoba hacía fuerza en no otorgar las apelaciones que el Ayuntamiento había interpuesto en el pleito, ordenando también en ella que se levantara pena de excomunión.

7 Y no fue la primera vez que hubo de resolver la monarquía, es decir, el Estado. En las Actas Capitulares de 1523, Cabildo del 29 de abril, ante el derribo por la Iglesia de la parte de la Mezquita, se dice que «la manera queste templo esta edificado es vnico en el mundo e q pa su edificio se gasto grand suma de tesoro y lo principal de yncoveniente es $q$ la capilla Real esta eincorporada en el altar mayor donde estan enterrados los reyes»... Y se añade que «otra vez que se yntento por el dean e cabildo atrás mando las dichas obras la católica rreyna dona Isabel q sea en gloria no lo consintió e mandaron q los letrados hordene vnreqimynto sobre este proposito e que el procurados mayor con vnescriti lo notifiq al dean e cabildo pa q cesen en dicha obra fasta q su majestad sea informado o mande lo mas sea su servycio». 
del Monarca, lo que es prueba de su naturaleza de bien de dominio público. Y si es de dominio público, tampoco puede ser usucapido o adquirido por su posesión prolongada en el tiempo.

Otro argumento que se esgrime es el relativo al hecho de que la «consagración» no es un modo de adquirir la propiedad. El art. 609 del Código Civil establece las diferentes vías para adquirir un derecho real sobre bienes susceptibles de propiedad privada. Y entre ellas, como es lógico, no puede ni debe aparecer la consagración ${ }^{8}$.

Tal como ya hemos señalado, el 2 de marzo de 2006, el Cabildo Catedralicio de Córdoba inmatriculó la Mezquita-Catedral con el nombre de «Santa Iglesia Catedral de Córdoba».

Esta inscripción se realizó por parte del Obispado de Córdoba en aplicación de los entonces vigentes artículos 206 de la Ley Hipotecaria y 304 de su Reglamento -los utilizados en las inmatriculaciones por los que se equipara a la Iglesia católica con el Estado y legitima a los diocesanos a expedir certificaciones pertinentes.

La Ley Hipotecaria (LH, en adelante), aprobada por Decreto de 8 de febrero de 1946, concedía en 2006 al Obispo Diocesano la categoría de funcionario público, para poder acreditar inmatriculaciones a través del juego combinado de los siguientes preceptos:

- Art 199 LH [Medios de inmatriculación de fincas no inscritas]

La inmatriculación de fincas que no estén inscritas a favor de persona alguna se practicará:

a) Mediante expediente de dominio.

b) Mediante el título público de su adquisición, complementado por acta de notoriedad cuando no se acredite de modo fehaciente el título adquisitivo del transmitente o enajenante.

c) Mediante el certificado a que se refiere el artículo 206, sólo en los casos que en el mismo se indican.

- Artículo 206 LH (primer párrafo)

El Estado, la provincia, el municipio y las Corporaciones de derecho público o servicios organizados que forman parte de la estructura política

${ }^{8}$ Cabe recordar que el Tribunal Supremo, en sentencia de 28 de diciembre de 1959 , dejó bien claro que el destino del culto de un inmueble no determina su titularidad. Igualmente se debe a traer a colación una referencia histórica de máximo interés debido al amplio periodo de vigencia de esta norma. Nos referimos a la Ley 12 del Título 28 de la Partida III: «Toda cosa sagrada o religiosa o santa que es establecida en servicio de Dios no es en poder de ningún hombre el señorio de ella, ni puede ser contada entre sus bienes; y aunque los clérigos las tengan en su poder, no tienen el señorio de ellas, mas tiénenlas así como guardadores y servidores». 
de aquél y las de la iglesia católica, cuando carezcan del título escrito de dominio, podrán inscribir el de los bienes inmuebles que les pertenezcan mediante la oportuna certificación librada por el funcionario a cuyo cargo esté la administración de los mismos en la que se expresará el título de adquisición o el modo en que fueron adquiridos.

- Artículo 207LH.

Las inscripciones de inmatriculación practicadas con arreglo a lo establecido en los dos artículos anteriores no surtirán efectos respecto de tercero hasta transcurridos dos años desde su fecha.

Esta normativa se desarrolla reglamentariamente del siguiente modo: 1998)

- Artículo 4 del Reglamento Hipotecario (Modificado parcialmente en

Serán inscribibles los bienes inmuebles y los derechos reales sobre los mismos, sin distinción de la persona física o jurídica a que pertenezcan, y por tanto, los de las Administraciones públicas y los de las entidades civiles o eclesiásticas.

- Artículo 304 del Reglamento Hipotecario (redacción de 1947)

En el caso de que el funcionario a cuyo cargo estuviese la administración o custodia de los bienes no ejerza autoridad pública ni tenga facultad para certificar, se expedirá la certificación a que se refiere el artículo anterior por el inmediato superior jerárquico que pueda hacerlo, tomando para ello los datos y noticias oficiales que sean indispensables. Tratándose de bienes de la Iglesia, las certificaciones serán expedidas por los Diocesanos respectivos.

El Obispado alegó que la Mezquita-Catedral le pertenecía por «consagración». Aunque pueda parecer de difícil entendimiento en un Estado aconfesional, el único argumento que necesitó para inmatricular la Mezquita-Catedral fue su «toma de posesión» en 1236, mediante el trazado sobre el pavimento de una franja de ceniza en forma de cruz diagonal con las letras de los alfabetos griego y latino.

No presentó título formal de propiedad ni acompañó sentencia judicial que reconociera una posible usucapión del monumento por su posesión prolongada en el tiempo.

La inmatriculación no otorga la titularidad del derecho que se inscribe, pero sí es cierto que genera la apariencia jurídica de su pertenencia, obligando a quien la cuestione, dado que no podría accionar el expediente de dominio establecido en la legislación hipotecaria, a recurrir potestativamente ante la Dirección General de los Registros y del Notariado o ser impugnadas directamente ante los juzgados de la capital de la provincia a la que pertenezca 
el lugar en que esté situado el inmueble, siendo de aplicación las normas del juicio verbal ${ }^{9}$.

\section{LA POSIBLE INCONSTITUCIONALIDAD DEL ARTÍCULO 206 LH}

Las repercusiones jurídicas de este artículo 206 LH han sido ampliamente analizadas por la doctrina ${ }^{10}$. Igualmente existen estudios relevantes ${ }^{11}$ sobre la vulneración de principios constitucionales por aplicación de la normativa bajo la cual se produjo la inmatriculación de la Mezquita-Catedral por parte de la Iglesia Católica. En este trabajo sólo resumiremos las principales líneas argumentales que nos pueden hacer pensar en dicha vulneración, remitiendo, de cara a un estudio más exhaustivo del asunto, al artículo «Privilegio inmatriculador de la Iglesia Católica y vulneración de principios constitucionales a la luz de la STEDH «Sociedad Anónima del Ucieza contra España» en

9 Artículos 322 y siguientes de la Ley Hipotecaria.

${ }^{10}$ Especialmente por Torres GutiÉrRez, A., «A propósito de la reforma del Reglamento Hipotecario por el Real Decreto 1867/1998, de 4 de septiembre, en materia de registro de los bienes inmuebles de titularidad eclesiástica», Boletín de la Sociedad Española de Ciencias de las Religiones, núm. 9, 1998, págs. 79 a 81. ToRres GuTiÉrREZ, A., «Estudio crítico de los privilegios de la Iglesia Católica en materia de inmatriculación de bienes», en VV.AA., Escándalo monumental. La privatización de las iglesias, ermitas, casas, tierras y otros bienes públicos en Navarra, Altaffaylla Kultur Aldea, Tafalla, 2009, págs. 183 a 193; y también por DE LA HAZA DíAZ, P., «Inmatriculación de bienes de la Iglesia mediante certificación expedida por el Diocesano», en Revista Crítica de derecho inmobiliario, año 71, núm. 630, 1995, pág. 1591 y ss.; MALUQUER DE MOTES BONET, C. J., «Titularidad de los montes vecinales y constitucionalidad o no del artículo 206 de la Ley Hipotecaria por lo que toca a los bienes de la Iglesia Católica. Comentario a la Sentencia del Tribunal Supremo (Sala 1. ${ }^{\text {a) }}$ de 18 de noviembre de 1996», Revista de Derecho Privado, Febrero de 1993, págs. 128 a 137; BALlarín HERNÁNDEZ, R., «Rectificaciones constitucionales a la vigencia actual de la certificación de dominio público como medio inmatriculador», Revista Crítica de Derecho Inmobiliario Registral, núm. 563, 1984, págs. 843 a 866; PeÑa Bernaldo DE Quirós, M., «Derechos Reales y Derecho Hipotecario», Derechos reales de garantía. Registro de la Propiedad, Centro de Estudios Registrales, Madrid, 1999, pág. 491; García GarcíA, J.M., Código de Legislación Hipotecaria $y$ del Registro Mercantil, 2. ${ }^{a}$ Edición, Madrid, 1990, pág. 97; Albaladejo, M., Derecho

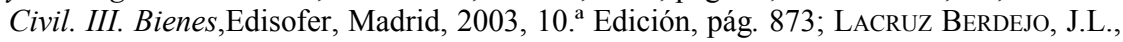
Sancho Rebullida, F. de A., Luna Serrano, A., Delgado Echeverría, J., Rivero Hernández, F., y Rams Albesa, J., Elementos de Derecho Civil. III bis. Derecho Inmobiliario Registral, Dykinson, Madrid, 2001, pág. 343;Rodríguez BlanCO, M., «Las certificaciones de dominio de la Iglesia Católica. Análisis del artículo 206 de la Ley Hipotecaria», Revista jurídica del Notariado, n. 34, Abril-Junio de 2000, págs. 276 y 277.

${ }_{11}$ Ver singularmente TORRES GUTIÉRREZ, A., En torno a la inconstitucionalidad del proceso inmatriculador de fincas de los artículos 206 de la Ley Hipotecaria y 304 de su Reglamento, consultado en <http://laicismo.org>, (consultado el 12-11-2014, a las $17.30 \mathrm{hs}$.) 
Revista Crítica de Derecho Inmobiliario, n. ${ }^{\text {o }} 751$, realizado por quien suscribe este trabajo.

\subsection{Por infracción del principio de aconfesionalidad del Estado}

La Constitución de 1978 reconoce la libertad ideológica, religiosa y de culto de los individuos y las comunidades sin más limitación, en sus manifestaciones, que la necesaria para el mantenimiento del orden público protegido por la Ley.

Este derecho reconocido en el artículo 16 conlleva que nadie podrá ser obligado a declarar sobre su ideología, religión o creencias.

El apartado tercero del artículo 16 establece la aconfesionalidad del Estado español y haciendo una mención expresa a la Iglesia Católica en estos términos: «Ninguna confesión tendrá carácter estatal. Los poderes públicos tendrán en cuenta las creencias religiosas de la sociedad española y mantendrán las consiguientes relaciones de cooperación con la Iglesia Católica y las demás confesiones».

Pues bien, con la entrada en vigor de la Constitución Española de 1978, se instaura un modelo en el que:

1. El Estado se encuentra separado de la Iglesia.

2. El Estado adopta una posición de neutralidad en sus relaciones con las confesiones religiosas y con los colectivos de ciudadanos no creyentes. La Iglesia Católica ya no es, tal como quedaba establecido en el régimen de Franco, Corporación de Derecho Público equiparable a las que forman parte de la organización política estatal (como opera a los efectos del artículo 206 de la Ley Hipotecaria). Porque ni los fines propios de la Iglesia coinciden con los del Estado, ni su actividad es homologable a la de los órganos del Estado.

3. Al afirmarse en el artículo 16.3 que ninguna confesión tendrá carácter estatal, es decir que la Iglesia se encuentra separada del Estado, éste debe adoptar una posición de exquisita neutralidad frente a las diversas creencias religiosas de los ciudadanos.

Pues bien, el artículo 206 de la Ley Hipotecaria es susceptible de ser declarado inconstitucional por atentar contra el principio de aconfesionalidad del Estado.

Se ha de afirmar que los principios de libertad e igualdad religiosa y de aconfesionalidad del Estado reconocidos en la Constitución Española chocan con el privilegio de la Iglesia para inmatricular bienes a su nombre con un certificado que firme el propio obispo.

Para llegar a estas conclusiones, resulta especialmente relevante el estudio de la STC 340/93, de 16 de noviembre, que declaró la inconstitucionali- 
dad del artículo 76.1 del Texto Refundido de la Ley de Arrendamientos Urbanos de 1964, que equiparaba a la Iglesia Católica con el Estado, la Provincia, el Municipio y las Corporaciones de Derecho Público, a la hora de no estar obligada a justificar la necesidad de ocupación de los bienes que tuviere dados en arrendamiento, lo que suponía una clara forma de facilitar la resolución de este tipo de contratos, fortaleciendo notablemente la posición del arrendador frente al arrendatario, cuando quien arrendaba esos bienes inmuebles era un ente eclesiástico.

Situación de privilegio que es claramente análoga a la que se plantea en relación a la inmatriculación de fincas, y que se declaró inconstitucional por atentar a los principios de igualdad y de aconfesionalidad del Estado.

La doctrina del Tribunal Constitucional la podemos resumir en estas dos conclusiones verdaderamente esclarecedoras, que son extrapolables íntegramente a este estudio:

1. Afirma que el precepto impugnado no encuentra acomodo en un Estado aconfesional, siendo en el fondo un resquicio de un modelo de relaciones Iglesia-Estado de corte confesional.

2. Entiende que el deber de cooperación del Estado con las confesiones religiosas establecido en el artículo 16.3 de la C.E. no da cobertura a este precepto porque en ningún caso las confesiones religiosas pueden trascender los fines que les son propios y ser equiparables al Estado ocupando una igual posición jurídica.

En este punto el Tribunal Constitucional viene a reiterar, pues, lo que afirmó anteriormente en la STC 24/1982, en la que expresamente se advertía que el artículo 16.3 C.E. veda cualquier confusión entre funciones religiosas $\mathrm{y}$ funciones estatales.

\subsection{Por infracción del principio de igualdad}

Como ha reconocido nuestro Tribunal Constitucional, al establecer el artículo 14 de la Constitución el principio general de que los españoles son iguales ante la ley, establece un derecho subjetivo a obtener un trato igual, impone a los poderes públicos la obligación de llevar a cabo ese trato igual y, al mismo tiempo, limita el poder legislativo y los poderes encargados de la aplicación de las normas jurídicas.

Ese trato igual significa que a los supuestos de hecho iguales han de serles aplicadas unas consecuencias jurídicas que sean iguales también y que para introducir diferencias entre los supuestos de hecho tiene que existir una suficiente justificación de tal diferencia que aparezca, al mismo tiempo, como fundada y razonable de acuerdo con criterios y juicios de valor generalmente aceptados. 
Es un derecho de naturaleza relacional y no autónomo, de manera que no se viola la igualdad en abstracto sino en relación con otros derechos. Además, en el citado precepto el constituyente trata de excluir cualquier diferencia de trato que carezca de una justificación objetiva y razonable por cualquier circunstancia personal o social.

Pues bien, en relación con el precepto cuestionado se aprecia claramente que existe un trato discriminatorio, que se separa de las más elementales notas caracterizadoras de la igualdad formal.

Por ello, para que pudiera entenderse avalado constitucionalmente el trato favorable otorgado a la Iglesia Católica por el artículo 206 de la Ley Hipotecaria, conviene analizar si existen razones materiales que justificaran dicho trato.

El Tribunal Constitucional español ha establecido, en una jurisprudencia bastante consolidada, las condiciones para que el establecimiento de un trato desigual constituya una diferenciación admisible.

En primer lugar, ha de darse una desigualdad de los supuestos de hecho. En segundo lugar, para que esta diferenciación esté constitucionalmente justificada la misma debe tener una finalidad razonable.

En tercer lugar, el trato diferenciador debe ser considerado racional. En cuarto y último lugar, entre todos estos elemento se exige la proporcionali$\mathrm{dad}$, fundamentalmente entre el trato desigual y la finalidad perseguida.

En el supuesto del trato favorable a la Iglesia Católica a efectos de la inmatriculación de fincas, no puede entenderse que la Iglesia Católica se encuentre en una situación especial, pues el proceso desamortizador desapareció hace más de un siglo, de modo que el contexto en que surge este privilegio, no puede equipararse a la actualidad, ni justifica una posible situación de utilidad o interés general a su favor.

Tal principio no exige un trato exactamente igual a todos los individuos, pues caben tales diferencias si están debidamente justificadas. La Sentencia del Tribunal Constitucional 340/1993, en su Fundamento Jurídico 4. ${ }^{\circ}$, letra c), señala respecto a la diferencia de trato que en el mencionado precepto se establecía entre los supuestos de titularidad del bien arrendado por parte de la Iglesia Católica y los de otra Confesión, o un particular, razonamiento que, por analogía, aplicamos en el asunto motivo de este trabajo:

1. Que no toda desigualdad de trato legislativo en la regulación de una materia entraña una vulneración del derecho fundamental a la igualdad ante la Ley del artículo 14 C.E., sino únicamente aquellas que introduzcan una diferencia de trato entre situaciones que puedan considerarse sustancialmente iguales y no posean una justificación objetiva y razonable. La justificación de este trato de favor para la Iglesia Católica encuentra un fundamento especialmente difícil desde el momento en que la propia jurisprudencia constitucional ha señalado que no hay 
una distinción objetiva en la posición jurídica de la Iglesia Católica y las demás personas físicas y jurídico privadas (las demás confesiones por ejemplo) que justifique una solución diferente.

2. Que para que la diferencia de trato sea constitucionalmente lícita, las consecuencias jurídicas que se deriven de tal diferencia deben ser proporcionadas a la finalidad perseguida por el legislador.

Tal juicio de proporcionalidad, ha manifestado el Tribunal Constitucional deberá recaer sobre el análisis conjunto de estos tres elementos:

a) La medida que se ha adoptado: estamos ante un trato de favor a la Iglesia Católica que no puede encontrar más justificación que la de haber tenido su génesis en un modelo de Estado confesional, en estos momentos superado.

b) El resultado producido: que no es otro que una vulneración del principio de aconfesionalidad del Estado.

c) La finalidad pretendida por el legislador en el supuesto concreto: que no es asumible por un Estado aconfesional en el que no cabe equiparar los fines religiosos con los fines públicos, ni emitir juicios de valor de carácter positivo referidos al hecho religioso en cuanto tal.

No existiría justificación a este trato de favor de la Iglesia Católica, ni por la finalidad que persigue la disposición ni por los efectos que la misma genera. El trato de favor que se evidencia en ayuda de la Iglesia Católica se manifiesta enormemente vinculado a un sentido confesional del Estado, ciertamente propio de una época determinada pero en nada parecido a la situación actual ni conforme con la Constitución, que proclama en su artículo 16.3 que «ninguna confesión tendrá carácter estatal». Por lo que estaríamos ante un caso de inconstitucionalidad sobrevenida.

\subsection{La STEDH «Sociedad Anónima del Ucieza contra España»}

Esta misma línea argumental ha sido avalada por la Sentencia del Tribunal Europeo de Derechos Humanos «Sociedad Anónima del Ucieza contra España», de 4 de noviembre de 2014, en la que considera que el Estado español violó el derecho de propiedad de la Sociedad Anónima del Ucieza en su litigio con la Diócesis de Palencia por la propiedad del monasterio de Ribas de Campos.

La Sociedad Anónima de Ucieza adquirió en 1978 una finca en Ribas de Campos (Palencia) en la que se enclava una iglesia cisterciense y algunos otros edificios adjuntos, como un molino de agua o una sacristía. Formaban parte en su día del monasterio de Santa Cruz de la Zarza, perteneciente a la Orden de los Premostratenses, orden desaparecida de España desde comien- 
zos del siglo XIX. En la inscripción registral de la adquisición de la finca por parte de la empresa en el Registro de Astudillo se detallaban todos estos edificios como parte del bien comprado.

Dieciséis años más tarde, sin embargo, el obispo de Palencia inscribió a su nombre esas instalaciones eclesiásticas valiéndose del privilegio contemplado en el artículo 206 de la Ley Hipotecaria. A pesar de la existencia de una previa inscripción registral a nombre de la Sociedad Anónima del Ucieza, tanto el registrador como los tribunales, en su momento, dieron por buena la inscripción registral realizada a nombre del Obispado de la Iglesia bajo el amparo del citado artículo 206.

La Sociedad Anónima del Ucieza apeló a los tribunales españoles sin éxito hasta llegar al Tribunal Supremo, que no admitió el recurso de casación, por la cuantía del objeto de litigio, y al Tribunal Constitucional, que en 2008, tampoco admitió el recurso de amparo.

El Obispado de Palencia siempre mantuvo que la desamortización eclesiástica de 1841 excluía a las iglesias, catedrales y anexos y que esas instalaciones seguían siendo, por tanto, propiedad de la diócesis.

El Tribunal de Estrasburgo ha declarado, por unanimidad, que el Estado español ha violado el artículo 6.1 del Convenio Europeo de Derechos Humanos, por la inadmisión del recurso de casación por el Tribunal Supremo. Este artículo expresa que «toda persona tiene derecho a que su causa sea escuchada equitativamente por un tribunal».

A los efectos de nuestro trabajo, lo que nos interesa resaltar es que por seis votos contra uno, el Tribunal considera también que se ha violado el artículo 1 del Protocolo 1 del Convenio, que enuncia que «toda persona física o moral tiene derecho al respeto de su bienes» y que solo se puede privar de tal derecho a alguien cuando hay una «utilidad pública», en relación al principio de igualdad contenido en el artículo 14.

Realmente este caso no es exactamente extrapolable al resto de denuncias por inmatriculaciones de la Iglesia católica, dado que en este caso las instalaciones religiosas sí estaban a nombre de alguien: el de la empresa. Normalmente, la Iglesia católica ha registrado a su nombre bienes que no están oficialmente a nombre de nadie aprovechando la potestad que le confiere la ley hipotecaria española, como es el caso de la Mezquita-Catedral de Córdoba.

La línea argumentativa del Tribunal, por la que se entiende violado el Convenio, en el aspecto que nos interesa en relación a este trabajo, se fundamenta $^{12}$ en que la inscripción registral del Monasterio a nombre del Obispado, con la única base del certificado expedido por el propio Obispo, supone una manera arbitraria y difícilmente predecible de inscripción que priva a

\footnotetext{
12 Párrafos 95 a 101 de la Sentencia.
} 
otros interesados de las garantías procesales básicas para la protección de sus derechos e intereses. En particular, el artículo 206 de la Ley Hipotecaria no satisface suficientemente las exigencias de precisión y previsibilidad que implica el concepto de ley tal como lo entiende el Convenio Europeo de Derechos Humanos.

La Corte de Estrasburgo considera aún más sorprendente que un certificado expedido por el Obispado pueda tener el mismo valor que los certificados emitidos por los funcionarios públicos, equiparándolo pues con los poderes públicos, y también se pregunta por qué el artículo 206 de la Ley Hipotecaria se refiere sólo a los obispos de la Iglesia Católica, con exclusión de los representantes de otras religiones. Asimismo, señala que no hay límite de tiempo para la inmatriculación y que ésta se realiza además sin publicidad, lo que implica una violación del principio de seguridad jurídica.

Igualmente, el Tribunal entiende que la desigualdad de trato ha de ser también tomada en consideración a la hora de entender la existencia de una violación del artículo 1 del Protocolo.

Así el Tribunal ${ }^{13}$ señala que «la ausencia de un debate y la desigualdad de armas, combinado con el obstáculo para el pleno disfrute de los derechos de propiedad y la falta de compensación, llevan al Tribunal a concluir que la demandante tuvo que soportar una carga especial y exorbitante que rompe el justo equilibrio que debe reinar entre las exigencias del interés general, por una parte, y la salvaguarda del derecho a la propiedad, por otro lado» ${ }^{14}$.

En relación al contenido de nuestro estudio, nos interesa destacar especialmente que, por virtud del artículo $10.2 \mathrm{CE}$, el contenido constitucional del derecho a la igualdad en relación al derecho de propiedad ha de interpretarse conforme a la doctrina emanada del Tribunal Europeo de Derechos Humanos.

\section{LA TUTELA DEL PATRIMONIO HISTÓRICO Y CULTURAL POR LA COMUNIDAD AUTÓNOMA DE ANDALUCÍA}

El desarrollo del Estado de las autonomías tiene seguramente uno de sus mejores paradigmas de referencia, tal como han señalado Porras y Agudo ${ }^{15}$, en relación a su temprana evolución en el sector de las políticas culturales

${ }^{13}$ Párrafo 101. Traducción propia desde la versión en Francés.

14 Ver casos Sporrong c. Lönnroth; Erkner c. Hofauer; 78 -79 c. Poiss; Almeida Garrett, MascarenhasFalcão y Otros c Portugal, entre otros citados por el propio TEDH en el Párrafo 101 de la Sentencia.

15 Porras Nadales, A. y Agudo Zamora, M., «Discurso y estrategia en la política cultural de la Junta de Andalucía» en Constitución y Cultura. Retos del Derecho Constitucional en el Siglo XXI, Tirant Monografías, Valencia, 2005, pág. 171 y ss. 
debido a toda una variada serie de razones: su temprano proceso transferencial, que implica un largo trayecto de experimentación y puesta en práctica; su consistente dimensión conflictual con el Estado central; su doble proyección en distintos ejes sustantivos que afectan y condicionan a las técnicas o estrategias de intervención (como mínimo en el doble ámbito de la conservación y del fomento); sus dificultades para progresar en entornos horizontales de cooperación y coordinación; y en definitiva, su tendencia a una constante reformulación de las principales líneas estratégicas que se proyectan a través del discurso.

En el contexto originario del proceso autonómico, a comienzos de la década de los ochenta, el bloque de las políticas culturales se configura en el tiempo como una de las primeras materias transferidas a Andalucía, a lo largo de una agenda que se inicia en 1981 hasta culminar prácticamente en 1984 (Reales Decretos 1075/1981, 4096/1982 y 864/1984). Por eso constituye al mismo tiempo una de las esferas donde desde una fecha más temprana se concentra la actividad de diseño legislativo, con las leyes andaluzas 8/1983 de Bibliotecas, 2/1984 de Museos, y 3/1984 de Archivos ${ }^{16}$. Posteriormente tiene lugar el desarrollo legislativo en la materia de patrimonio histórico, con la Ley 1/1991, de 3 de julio, de Patrimonio Histórico de Andalucía (previamente el Decreto 107/1989 había creado el Instituto Andaluz del Patrimonio Histórico) ${ }^{17}$.

Cabe sugerir además que, en términos generales, la estrategia de la política cultural ha estado inspirada en un discurso asentado sobre valores propios del Estado social, definiendo como horizontes finalistas los principios de igualdad de todos ante el hecho cultural, evitando discriminaciones; de solidaridad, emprendiendo políticas activas que deben incidir en los sectores menos favorecidos; de participación, promoviendo igualmente la efectiva intervención de los ciudadanos en las manifestaciones culturales; y finalmente el objetivo del equilibrio territorial, que en rigor se configura más bien como un elemento estratégico de carácter vertebrador, a fin de evitar y corregir los desequilibrios y desigualdades en la distribución de la infraestructura y la actividad cultural.

${ }^{16}$ Se trata ciertamente de leyes que aparecen en pleno momento inicial de fuerte conflictividad con el Estado, dando lugar así a la vía de inconstitucionalidad contra la Ley de archivos que no se resolvió finalmente hasta la Sentencia 103/1988 del Tribunal Constitucional.

${ }_{17}$ El posterior desarrollo reglamentario marca un cierto retraso en la agenda, culminando el año 1987 con el Decreto 323/1987 que constituye el Archivo General de Andalucía, y bastante tiempo después la Orden de 14 de septiembre de 1993 aprueba el Plan de Archivos. El Reglamento de Protección y Fomento del Patrimonio Histórico de Andalucía fue aprobado mediante el Decreto 19/1995; el Reglamento de Museos mediante el Decreto 284/1995; posteriormente el Decreto 230/1999 diseñó el Reglamento del Sistema Bibliotecario de Andalucía, y el 97/2000 el Reglamento del Sistema Andaluz de Archivos. 
Estos grandes principios orientadores de la acción han tenido que desenvolverse en dos campos estratégicos bien diferenciados: por una parte la tutela del patrimonio histórico y de las instituciones del patrimonio cultural, que implican una labor esencialmente conservacionista; y por otra, las funciones de fomento y promoción de las distintas manifestaciones artísticas, implicando una posición activa de mayor dificultad que acaba teniendo como referente último el desafío de la cooperación en materia cultural.

Centrándonos en la referente a la tutela del patrimonio histórico, cabe destacar que la primera dificultad a la que se enfrenta la política de patrimonio histórico en Andalucía consiste en su gran volumen cuantitativo. Puede recordarse, por ejemplo, que sobre la década de los años ochenta el conjunto de elementos declarados incoados en Andalucía superaban el millar, ascendiendo la cifra de los catalogados a unos 11.000, prácticamente el triple de lo incoado y catalogado en Cataluña, y algo por encima de los niveles de Castilla-León (comunidad que sigue a Andalucía en cuanto a elementos de patrimonio histórico), dado que se incluyen vestigios de prácticamente todas las civilizaciones habidas en el Mediterráneo occidental desde el Paleolítico.

Ello implicó que los primeros factores configuradores de la política dependían de una adecuada estrategia de catalogación, en torno a la cual se orientara la labor de la Consejería de Cultura durante la década de los ochenta, hasta alcanzar su formalización en el primer Plan General de Bienes Culturales de 1989-95, donde el principal eje argumentativo se situaba en torno a la protección del patrimonio frente a los factores de riesgo que trae consigo el fenómeno general del crecimiento socioeconómico y la presencia de una fuerte presión turística sobre los bienes culturales. El citado plan definía como objetivo central la tutela integral de los bienes de interés cultural en Andalucía, tanto muebles como inmuebles, articulando sus líneas de actuación en torno a tres programas fundamentales: la protección, la conservación y restauración, y las instituciones del patrimonio histórico ${ }^{18}$.

Bajo la noción de protección se integran básicamente el registro de los bienes y su inclusión dentro de un concreto marco legal de protección, ya sea un régimen general o especial. En cuanto a la conservación y restauración constituyen lógicamente elementos de dificultad añadida al implicar una determinada intervención sobre los bienes culturales, configurándose así como la fase más discutida y polémica en la medida en que implica una aplicación a elementos del pasado de todo un conjunto de exigencias y de innovaciones

${ }^{18}$ Debe destacarse la presencia de un primer esfuerzo de innovación conceptual, al introducirse la original categoría del «bien cultural», de origen italiano, que en principio se entendía como una noción superadora de la tradicional noción de lo "histórico-artístico», implicando así la incorporación a la noción de patrimonio de una nueva dimensión socioeconómica, que se incorporaría a la estrictamente cultural. 
tecnológicas propias del presente. Los elementos nucleares de la protección, conservación y restauración se complementarían con un programa instrumental de carácter institucional que se va a articular en torno a archivos, museos y conjuntos monumentales, implicando la puesta en marcha de una administración que se distribuye en la escala provincial y se articula en diversas instituciones específicas, apoyada en un específico programa de investigación. Finalmente la proyección hacia fuera de la política se canalizaría a través de un programa de difusión que pretenderá valorizar socialmente el conjunto patrimonial, dando lugar al desarrollo de gabinetes pedagógicos, a la organización de exposiciones y a la política de publicaciones.

Durante esta primera etapa tiene lugar la aprobación de la Ley 1/1991, de Patrimonio Histórico de Andalucía, donde se configuraba el Catálogo General del Patrimonio Histórico Andaluz ${ }^{19}$. A partir de mediados de los años 90 se pone en marcha una revisión general de la política que culminará en el nuevo plan del año 2000, donde tiene lugar la introducción generalizada del nuevo discurso europeo que se formaliza a partir de la Cumbre de Essen y del Libro Blanco de Jacques Delors en 1994, en torno a la configuración del patrimonio cultural como un potencial instrumento de desarrollo local y de promoción ocupacional, pasando así a ser entendido como uno de los campos estratégicos de surgimiento de nuevos yacimientos de empleo ${ }^{20}$.

A partir de mediados de los años 90, debido tanto a las iniciativas de la UNESCO como a la propia Unión Europea, comienza efectivamente a generalizarse el nuevo paradigma de «la cultura para el desarrollo», implicando una concepción de los gastos asignados a la conservación del patrimonio cultural como verdaderas inversiones que, a corto o medio plazo, deben dar sus frutos al traducirse en rentabilidad económica y social. El patrimonio cultural pasa así a entenderse como una entidad dinámica capaz de generar (como indicaba el Consejo de la Unión Europea, en sus conclusiones de 17 de diciembre de 1999 sobre las industrias culturales y el empleo en Europa) determinadas repercusiones económicas, ya sean directas, indirectas o inducidas, configurando así un marco idóneo para la promoción del

${ }_{19}$ Igualmente durante su periodo de vigencia se aprueban los Reglamentos sobre Archivos (Decreto 73/1994), Sistema Bibliotecario (Decreto 74/1994) y Museos (Decreto 285/1995).

${ }^{20}$ En realidad se trata de una línea que se había iniciado en parte con anterioridad, a partir de 1985, con las iniciativas de las Escuelas Taller y Casas de Oficios: un programa del Ministerio de Trabajo y Seguridad Social financiado básicamente por el Fondo Social Europeo, por el Estado y los municipios, y aplicado al patrimonio histórico inmueble como elemento catalizador de cada proyecto. Se trata de proyectos de desarrollo local integrado o desarrollo sostenible, con una amplia repercusión en Andalucía a través de la esfera local, alcanzando alrededor de doscientas Escuelas-Taller que canalizan más de la mitad de su actividad en sectores relacionados con el patrimonio histórico. 
empleo y el desarrollo de la calidad de vida en el singular entorno de la vieja Europa.

En torno a este nuevo horizonte finalista se puso en marcha el Plan de Bienes Culturales 2000, entendido como el instrumento de planificación y gestión adecuado a esta nueva concepción de la cultura concebida como un potencial instrumento motor del desarrollo regional de Andalucía ${ }^{21}$.

No obstante, la introducción de este nuevo discurso no implicó una ruptura inmediata con los anteriores argumentos finalistas, que en rigor no experimentaron una transformación radical. Así, el Plan General de Bienes Culturales establecía los objetivos de asegurar la preservación de los bienes culturales para el futuro, garantizar el acceso de todos los ciudadanos a su conocimiento y disfrute, promover el uso y la rentabilidad respetuosos y sostenibles de los bienes culturales, impulsar la participación de todos los agentes posibles en la gestión de los bienes culturales, y perfeccionar los métodos y desarrollar nuevos instrumentos de tutela.

Lo que se tradujo en unas líneas instrumentales que implicaron más bien una reordenación y ampliación sistemática de las anteriores pautas de acción: por una parte podríamos situar las acciones sustantivas de conservación, que implican la identificación del patrimonio y la sistematización de su información, junto al impulso a la investigación y el perfeccionamiento en el ámbito técnico y científico. Por otra, aparece la exigencia de mejorar la eficacia de los instrumentos de protección desde una nueva perspectiva integral que debería incluir el papel del patrimonio histórico como factor de estructuración territorial y desarrollo socioeconómico de Andalucía, implicando en consecuencia líneas de actuación destinadas a implementarse en conexión con otras políticas de desarrollo regional, comarcal o local, donde aparezcan recursos que formen parte del patrimonio histórico. Pero junto a estas orientaciones finalistas aparecía igualmente la exigencia de racionalizar las prioridades de inversión en materia de conservación y restauración, buscando, ante la inexorable limitación de recursos, la financiación compartida con otros agentes, tanto a escala regional como en la esfera comarcal o local. Y finalmente, aparecían las actuaciones de difusión, dirigidas tanto a los ciudadanos en general como a la comunidad escolar en particular.

En todo caso, la evolución del discurso programático no excluye que el contenido originario de la conservación y restauración del patrimonio históri-

${ }^{21}$ El Patrimonio Histórico se enfrenta así, junto a su carácter propio de testimonio de la civilización que debe ser preservado, a su transformación en un recurso fundamental para las estrategias de desarrollo territorial; de ser entendido como un sector de mera imputación de gasto, a ser considerado como fuente de riqueza generadora de empleo especializado, investigación aplicada, y dinamización del territorio, con capacidad para potenciar determinados circuitos de interés turístico y para estimular la actividad productiva. 
co, tanto mueble como inmueble, siga constituyendo uno de los elementos básicos de la planificación estratégica cultural en Andalucía, aunque ahora la relativa limitación de recursos disponibles aconseje que únicamente se deberá intervenir sobre el patrimonio cuando se trate de garantizar su conservación, acrecentar su conocimiento o fomentar su difusión; lo que implica la necesidad de que los poderes públicos prioricen sus inversiones en esta materia mediante la elaboración de específicos planes y programas de intervención.

Parece pues evidente que el nuevo contexto responde a un razonable aprendizaje sobre la inevitable limitación de los recursos públicos disponibles, y sobre las propias insuficiencias del sector público, lo que conducirá finalmente hacia un llamamiento a la corresponsabilidad social, bajo el postulado de que si el Patrimonio es de todos, todos debemos ayudar a su permanencia. En última instancia se trata pues de orquestar un equilibrio inversor entre todos los agentes que operan sobre el mismo, ya sean regionales, comarcales o locales, públicos o privados; teniendo en cuenta, por una parte, la manifiesta escasez de recursos públicos para la conservación de un patrimonio tan rico y complejo como el andaluz y, por otro, por entender que sobre la administración autonómica no puede recaer en exclusiva el compromiso de su salvaguardia.

En 2007, se aprueba la Ley 14/2007, de 26 de noviembre, del Patrimonio Histórico de Andalucía ${ }^{22}$, que sustituye a la Ley $1 / 1991$. Tal como se señala en la Exposición de Motivos de dicha norma, el ejercicio de la potestad legislativa en esta materia se deriva del mandato que la Constitución Española dirige, en su artículo 46, a los poderes públicos para que garanticen la conservación y promuevan el enriquecimiento de nuestro patrimonio y de los bienes que lo integran, que tuvo su reflejo en el Estatuto de Autonomía para Andalucía de 1981 cuando, en su artículo 12.3, se refería a la protección y realce del Patrimonio Histórico como uno de los objetivos básicos de la Comunidad Autónoma.

Al mismo tiempo, la promulgación de la citada Ley 1/1991 tuvo su soporte competencial en los artículos 148.1.16.. ${ }^{\mathrm{a}}$ y 149.1.28.. ${ }^{\mathrm{a}}$ de la Constitución

${ }^{22}$ Para un estudio más profundo sobre esta norma pueden consultarse, entre otras obras: Martínez de Carvajal, I., «La Ley del Patrimonio Histórico de Andalucía (2007): Catalogación y descontaminación. Nuevos retos; viejos retos», Patrimonio histórico: retos, miradas, asociaciones e industrias culturales / coord. por Rafael Jesús López Guzmán, 2010, págs. 43-64; Martínez DE CARVAJAL, I., «La Ley del Patrimonio Histórico Andaluz (2007) y el Planeamiento Urbanístico», E-rph: Revista electrónica de Patrimonio Histórico, n. ${ }^{\circ}$. 3, 2008, 28 págs.; LóPEz Reche, G., «La Ley Andaluza de Patrimonio Histórico: novedades significativas», en LóPEZ GuZMÁN, R.J. (Coord.), Patrimonio histórico: retos, miradas, asociaciones e industrias culturales, 2010, págs. 19-42; CRUZ ArCos, E., «La Ley 14/2007, de 14 de noviembre, de Patrimonio Histórico de Andalucía: principales contenidos e innovaciones», Patrimonio cultural y derecho, n. ${ }^{\circ}$ 14, 2010, págs. 47-63. 
Española, así como lo tenía en el artículo 13.27 del Estatuto de Autonomía para Andalucía de 1981.

La experiencia acumulada en la aplicación de la Ley 1/1991, de 3 de julio, de Patrimonio Histórico de Andalucía, la evolución de los conceptos y planteamientos en que se basan la protección y conservación, así como los cambios legislativos producidos en otras áreas del ordenamiento jurídico estrechamente vinculadas a la que nos ocupa aconsejaban proceder a una reforma en profundidad de la Ley de 1991.

A partir de la entrada en vigor del Estatuto de Autonomía para Andalucía de $2007^{23}$, el fundamento de la nueva Ley de Patrimonio Histórico de Andalucía se encuentra en el artículo 10.3.3. ${ }^{\circ}$, que se refiere al afianzamiento de la conciencia de identidad y de la cultura andaluza a través del conocimiento, investigación y difusión del patrimonio histórico como uno de los objetivos básicos de la Comunidad Autónoma. A su vez, el artículo 68.3.1. el Estatuto de Autonomía para Andalucía atribuye a la Comunidad Autónoma la competencia exclusiva en materia de protección del patrimonio histórico, artístico, monumental, arqueológico y científico.

Por otra parte, en el artículo 33 del Estatuto se reconoce el derecho de todas las personas al acceso, en condiciones de igualdad, a la cultura, al disfrute de los bienes patrimoniales, artísticos y paisajísticos, y, correlativamente, en el artículo 36, el deber de respetar y preservar el patrimonio público, en su vertiente cultural, histórico-artístico y natural.

Por ello, tal como establece el artículo 37.1.18. ${ }^{\circ}$, los poderes públicos orientarán sus políticas públicas a garantizar el libre acceso de todos a la cultura y el respeto a la diversidad cultural y la conservación y puesta en valor del patrimonio cultural, histórico y artístico de Andalucía, especialmente del flamenco ${ }^{24}$.

${ }^{23}$ Estudios profundos de los motivos y contenido del nuevo Estatuto andaluz pueden consultarse, entre otros, en MuÑoz Machado, S. y Rebollo Puig, M. (Coords.), Comentarios al Estatuto de Autonomía para Andalucía, Thomson-Civitas, Navarra, 2008; AGUDo Zamora, M. (Coord.), El Estatuto de Autonomía de Andalucia de 2007, Centro de Estudios Andaluces, Sevilla, 2007; Balaguer Callejón, F. y otros, El nuevo Estatuto de Andalucía, Tecnos, Madrid, 2007; Terol BeCERra, M. (Coord.), La reforma del Estatuto de Autonomía para Andalucía: posibilidades y límites, Instituto Andaluz de Administración Pública, Sevilla, 2005; Terol Becerra, M. (Coord.), La reforma del Estatuto de Autonomía para Andalucia: pareceres, Instituto Andaluz de Administración Pública, Sevilla, 2007; Terol Becerra, M.J. (Coord.), El Estado autonómico «in fieri». La Reforma de los Estatutos de Autonomía, IAAP, Sevilla, 2005; Reforma del Estatuto de Autonomía para Andalucía. Parlamento de Andalucía, Centro de Publicaciones no Oficiales, Sevilla, 2005.

${ }^{24}$ Con anterioridad a la reforma del Estatuto andaluz ya podíamos encontrar algunas referencias legislativas al derecho de «todos» a la cultura, fiel reflejo del esfuerzo de los 
Por otra parte, y retomando el objeto principal de estudio de este trabajo, el artículo 33 de la Ley de Patrimonio Histórico de Andalucía, referente a la autorización de intervenciones, prohibiciones y deber de comunicación sobre inmuebles, establece en su apartado $3 .^{\circ}$ que «será necesario obtener autorización de la Consejería competente en materia de patrimonio histórico, con carácter previo a las restantes licencias o autorizaciones que fueran pertinentes, para realizar cualquier cambio o modificación que los particulares u otras Administraciones Públicas deseen llevar a cabo en inmuebles objeto de inscripción como Bien de Interés Cultural o su entorno, tanto se trate de obras de todo tipo, incluyendo remociones de terreno, como de cambios de uso o de modificaciones en los bienes muebles, en la pintura, en las instalaciones o accesorios recogidos en la inscripción». Aunque este precepto parece estar pensado para cambios o modificaciones de carácter material, podría interpretarse también que un cambio o modificación de tanta repercusión jurídica como es la inscripción registral de la Mezquita-Catedral debería haberse comunicado por parte de la Iglesia Católica a la Junta de Andalucía, con carácter previo.

Pues bien, atendiendo a todo lo expuesto, tanto en clave estatutaria como legislativa, sobre el asunto, debemos destacar:

1. Existen dudas razonables acerca de la titularidad de la MezquitaCatedral.

2. Parecen existir argumentos sólidos para entender que la inmatriculación de la Mezquita-Catedral por parte de la Iglesia Católica se ha

poderes públicos de promover el progreso de la cultura, en consonancia con el preámbulo y los artículos 44 y 46 de la Constitución. A título de ejemplo, mencionamos el artículo 4.1 de la derogada Ley 2/1984, de 9 de enero, de museos, el cual establecía literalmente que «el acceso a los museos de titularidad autonómica será totalmente gratuito para los ciudadanos españoles, los extranjeros residentes en España, los menores de veintiún años procedentes de países de la Comunidad Económica Europea y ciudadanos de los países hispanoamericanos». Igualmente, la Ley 16/2003, de 22 de diciembre, del Sistema Andaluz de Bibliotecas y Centros de Documentación, artículo 16: «1. Los titulares y, en general, los responsables o gestores de los servicios de la Red de Bibliotecas Públicas de Andalucía deberán prestar especial atención a las personas, grupos sociales y zonas geográficas que se encuentran en situación de desventaja, de manera que se garantice su efectivo acceso a los registros culturales y de información. 2. Asimismo, deberán garantizar a los inmigrantes el acceso a la información, así como a los materiales que les ayuden tanto a su integración social como a preservar su lengua y cultura original. Igualmente se fomentará que se seleccionen materiales y se ofrezcan colecciones en la lengua de los mismos. 3. En la planificación y en la gestión de los centros de la Red de Bibliotecas Públicas de Andalucía se arbitrarán los medios necesarios para que las personas impedidas para asistir a la biblioteca pública por enfermedad, discapacidad, edad o privación de libertad, tengan acceso a los registros culturales y de información». 
realizado al amparo de una ley que adolece de vicios de inconstitucionalidad.

3. Atendiendo a las competencias atribuidas a la Comunidad Autónoma de Andalucía tanto por la Constitución como por el Estatuto de Autonomía para Andalucía, y reflejadas en la legislación vigente sobre patrimonio histórico, así como por el Real Decreto 864/1984, de 29 de febrero, sobre traspaso de funciones y servicios del Estado a la Comunidad Autónoma de Andalucía en materia de cultura, por el que se traspasan las competencias de tutela de la Mezquita-Catedral a nuestra Comunidad Autónoma, la Junta de Andalucía podría considerar la necesidad y oportunidad de promover las acciones que aclaren constitucionalmente este asunto.

4. Una vez expuestas, en los apartados anteriores, las causas de una posible inconstitucionalidad del artículo 206 de la Ley Hipotecaria, analicemos, a continuación, la vía de impugnación del mismo, a través de la cuestión de constitucionalidad.

\section{LA IMPUGNACIÓN DEL ARTÍCULO 206 LH A TRAVÉS DE UNA CUESTIÓN DE CONSTITUCIONALIDAD ${ }^{25}$}

La eficacia directa de la Constitución obliga a los tribunales a utilizar para la solución de los conflictos jurídicos las normas constitucionales y el resto de las normas del ordenamiento constitucional.

Los problemas surgen cuando en un proceso determinado los jueces o tribunales que conocen del asunto tienen que decidir entre aplicar la Constitución y una ley o norma con rango de ley sobre la que alberguen dudas de constitucionalidad. Un sistema de eficacia directa puro obligaría al juez a aplicar directamente la Constitución y desechar el precepto de la norma inconstitucional, como sería el caso del sistema difuso norteamericano de garantía constitucional. Pero nuestro modelo concentrado no admite que los jueces se conviertan en jueces de la constitucionalidad de la Ley, atribuyendo el monopolio de la declaración de inconstitucionalidad al Tribunal Constitucional ${ }^{26}$.

${ }^{25}$ Ver AGUdo Zamora, M., «Privilegio inmatriculador de la Iglesia Católica y vulneración de principios constitucionales a la luz de la STEDH "Sociedad Anónima del Ucieza contra España”», Revista Crítica de Derecho Inmobiliario, n. ${ }^{\circ} 751,2015$, págs. 2650 y 2651.

${ }^{26}$ Así lo declaraba el Tribunal Constitucional en una de sus primeras resoluciones, «no corresponde al Poder Judicial el enjuiciar al Poder legislativo en el ejercicio de su función peculiar, pues tal enjuiciamiento está atribuido al Tribunal Constitucional» (STC 4/1981, F J 1,c). Y lo desarrollaba por extenso, en la STC 17/1981: «La cuestión de inconstitucionalidad no es una acción concedida para impugnar de modo directo y con carácter abstracto la validez de la ley, sino un instrumento puesto a disposición de 
La cuestión de inconstitucionalidad del art. 163 de la Constitución se convierte así en el instrumento que permite combinar la eficacia directa de la Constitución, que obligaría a incumplir las normas inconstitucionales, y el deber de sometimiento de los jueces y tribunales a la Ley en el ejercicio de su función jurisdiccional: «Cuando un órgano judicial considere, en algún proceso, que una norma con rango de Ley, aplicable al caso, de cuya validez dependa el fallo, pueda ser contraria a la Constitución, planteará la cuestión ante el Tribunal Constitucional en los supuestos, en la forma y con los efectos que establezca la Ley, que en ningún caso serán suspensivos».

La cuestión se define, pues, como un supuesto de control concreto impropio, con una doble naturaleza. Desde una perspectiva procesal se comporta como una cuestión prejudicial devolutiva ${ }^{27}$, en la que juega un papel fundamental la existencia de un proceso principal tanto para la admisión como para la subsistencia de la cuestión constitucional. Desde una perspectiva constitucional, además de un instrumento de colaboración entre la jurisdicción ordi-

los órganos judiciales para conciliar la doble obligación en que se encuentran de actuar sometidos a la ley y a la Constitución. La estricta aplicación del principio de jerarquía permitiría al juez resolver el dilema en que lo situaría la eventual contradicción entre la Constitución y la ley con la simple inaplicación de ésta, pero ello hubiera implicado someter la obra del legislador al criterio tal vez diverso de un elevado número de órganos judiciales, de donde podría resultar, entre otras cosas, un alto grado de inseguridad jurídica. El constituyente ha preferido, para evitarlo, sustraer al juez ordinario la posibilidad de inaplicar la ley que emana del legislador constituido, aunque no la de cuestionar su constitucionalidad ante este Tribunal que, en cierto sentido, es así, no sólo defensor de la Constitución, sino defensor también de la ley. La defensa de la Constitución frente a las eventuales extralimitaciones de los órganos dotados de poder para crear normas de carácter general corresponde, en primer lugar, a los jueces y Tribunales, que han de negar validez, a las normas reglamentarias que sean contrarias a la Constitución, inaplicándolas, y están facultados para inaplicar también incluso las normas legales que adolezcan del mismo defecto, cuando sean anteriores a la Constitución. La supremacía de ésta obliga también a los jueces y tribunales a examinar, de oficio o a instancia de parte, la posible inconstitucionalidad de las leyes en las que, en cada caso concreto, hayan de apoyar sus fallos, pero, en defensa, como antes se dice, de la dignidad de la ley emanada de la representación popular, el juicio adverso a que tal examen pueda eventualmente conducirlos no los faculta para dejar sin más de aplicarlas, sino sólo para cuestionarlas ante este Tribunal. La depuración continua del ordenamiento desde el punto de vista de la constitucionalidad de las leyes, y siempre a salvo la acción del propio legislador, es así resultado de una colaboración necesaria entre los órganos del poder judicial y el Tribunal Constitucional, y sólo esta colaboración puede asegurar que esta labor depuradora sea eficaz y opere de manera dinámica y no puramente estática, ya que sólo por esta vía, y no por la del recurso de inconstitucionalidad, cabe tomar en consideración el efecto que la cambiante realidad social opera sobre el contenido de las normas» (F J 1).

27 ATC 69/83. 
naria y la constitucional para garantizar la integridad de la CE, es un instrumento más de control abstracto de la constitucionalidad de las leyes ${ }^{28}$, que presenta la ventaja de evitar los elementos más sensibles de la politización que en la práctica manifiesta el recurso directo de constitucionalidad.

En relación al asunto que estudiamos en este trabajo, una vía para explorar la posibilidad de que se planteara una cuestión de constitucionalidad sería la siguiente:

1. ${ }^{\circ}$ La Junta de Andalucía podría dirigirse al Registro de la Propiedad con la finalidad de inscribir la Mezquita-Catedral a su nombre, mediante la oportuna certificación librada por el funcionario a cuyo cargo esté la administración de los mismos ${ }^{29}$ (artículo 206 LH y 304 RH).

Esta pretensión se realizaría con base en:

- Informe pericial de expertos en Historia del Derecho, que avalara la titularidad pública de la Mezquita-Catedral.

- Real Decreto 864/1984, de 29 de febrero, sobre traspaso de funciones y servicios del Estado a la Comunidad Autónoma de Andalucía en materia de cultura.

2. ${ }^{\circ}$ El Registro de la Propiedad, probablemente, calificará negativamente este documento. Con base en los artículos 322 y siguientes de la Ley Hipotecaria, podrá recurrirse potestativamente ante la Dirección General de los Registros y del Notariado o ser impugnadas directamente ante los juzgados de la capital de la provincia a la que pertenezca el lugar en que esté situado el inmueble, siendo de aplicación las normas del juicio verbal. De cara a una mayor eficacia en la resolución del asunto parece más aconsejable esta segunda opción.

3. En la demanda ante los Tribunales se plantearía la cuestión de constitucionalidad

4. ${ }^{\circ}$ En caso de que se reconociera vía cuestión de constitucionalidad la inconstitucionalidad del artículo $206 \mathrm{LH}$, se anularía la inscripción registral realizada por el Obispado de Córdoba

5. En relación a la inmatriculación realizada por la Junta de Andalucía, posiblemente sería impugnada por el Obispado.

${ }^{28}$ STC 94/86.

29 Acompañando (art.303 RH): $1 .^{\circ}$ La naturaleza, situación, medida superficial, linderos, denominación y número, en su caso, y cargas reales de la finca que se trate de inscribir. 2. ${ }^{\circ}$ La naturaleza, valor, condiciones y cargas del derecho real inmatriculable de que se trate y las de la finca a que se refiere la regla anterior. $3 .^{\circ}$ El nombre de la persona o corporación de quien se hubiere adquirido el inmueble o derecho, cuando constare. $4 .^{\circ} \mathrm{El}$ título de adquisición o el modo como fueron adquiridos. $5 .^{\circ} \mathrm{El}$ servicio público u objeto a que estuviere destinada la finca. 
6. ${ }^{\circ}$ En todo caso, todo este hipotético iter procesal sólo resolvería la cuestión referida a la inmatriculación de la Mezquita-Catedral, no la referente a la titularidad del dominio de la misma que quedaría pendiente de resolución.

\section{CONCLUSIONES}

1. El artículo 206 de la Ley Hipotecaria es susceptible de ser declarado inconstitucional por atentar contra el principio de igualdad (art. 14 CE) y el de aconfesionalidad del Estado (art. 16.3 CE).

Se puede afirmar, pues, que los principios de igualdad religiosa y de aconfesionalidad del Estado reconocidos en la Constitución Española chocan con el privilegio de la Iglesia para inmatricular bienes a su nombre con un certificado que firme el propio obispo, por las siguientes razones jurídicas:

a) El principio de aconfesionalidad impide dotar a las Confesiones religiosas del estatuto de Corporaciones de Derecho Público, no cabiendo asimilar los fines religiosos con los públicos, ni a los miembros de una Confesión religiosa, por muy cualificada que sea su posición dentro de la misma, con los funcionarios públicos.

b) Que la doctrina establecida por la Sentencia del Tribunal Constitucional 340/1993, de 16 de noviembre, respecto al artículo 76.1 del Texto Refundido de la Ley de Arrendamientos Urbanos de 24 de diciembre de 1964 es plenamente trasladable a los artículos 206 de la Ley Hipotecaria y 304 de su Reglamento, constituyendo base suficiente para plantear un recurso ante el Tribunal Constitucional.

c) En la medida que persista el mantenimiento de estos preceptos, se estará contraviniendo manifiestamente la doctrina del Tribunal Constitucional tendente a vedar cualquier confusión entre funciones religiosas y funciones estatales, recogida en el Fundamento Jurídico $4 .^{\circ}$, letra d) de la Sentencia 340/1993, y el Fundamento Jurídico 1. ${ }^{\circ}$ de la Sentencia 24/1982.

d) En relación al principio de igualdad entre confesiones religiosas reconocidas en el Estado, la solución nunca pasaría por equiparar a las distintas religiones para que todas ellas pudieran inmatricular bienes, pues de ese modo lo que se conseguiría es una lesión aún mayor del principio de aconfesionalidad del Estado.

2. La declaración de inconstitucionalidad de este artículo haría avanzar una línea jurisprudencial, iniciada por el Tribunal Constitucional en la STC 340/93, que puede abrir camino para contribuir sensiblemente a depurar determinadas áreas de nuestro ordenamiento jurídico sobre las que pueden recaer fundadas sospechas de inconstitucionalidad por ser resquicios de un 
modelo de relaciones Iglesia-Estado de corte confesional, que fue superado con la entrada en vigor de la Constitución Española de 1978, que instaura un modelo en el que:

1. El Estado se encuentra separado de la Iglesia.

2. El Estado adopta una posición de neutralidad en sus relaciones con las confesiones religiosas y con los colectivos de ciudadanos no creyentes.

3. Tomando el caso de la inscripción de la Mezquita-Catedral como referente, podría accionarse la vía judicial ordinaria, como camino para poder solicitar la cuestión de constitucionalidad. De este modo por vía jurisprudencial, se incidiría en la idea de laicidad del Estado, fórmula que no se incluyó en nuestra Constitución, y que ha de caracterizarse por la adopción de una posición de exquisita neutralidad frente a las diversas creencias religiosas de los ciudadanos y por una estricta separación con el hecho religioso.

Se trataría de apostar por una nueva manera de enfocar las relaciones entre la Iglesia y el Estado, que debería ir acompañada de otras numerosas modificaciones legales, que las hicieran equiparables a la realidad jurídicopolítica de la mayoría de los países europeos.

Se trataría, en definitiva, de profundizar en la idea de un Estado laico, evolución institucional y jurídica, propia de un Estado social y democrático de Derecho. Y que con el planteamiento de este recurso, bien explicado a la ciudadanía, sin demagogias ni radicalismos anticlericales, se visibilizaría claramente.

4. En relación a la inmatriculación de la Mezquita-Catedral:

a) Existen dudas razonables acerca de la titularidad de la Mezquita-Catedral.

b) Parecen existir argumentos sólidos para entender que la inmatriculación de la Mezquita-Catedral por parte de la Iglesia Católica se ha realizado al amparo de una ley que adolecía de vicios de inconstitucionalidad.

c) Atendiendo a las competencias atribuidas a la Comunidad Autónoma de Andalucía y a la legislación vigente sobre patrimonio histórico, así como por el Real Decreto 864/1984, de 29 de febrero, la Junta de Andalucía debe considerar la necesidad y oportunidad de promover las acciones que aclaren constitucionalmente este asunto, máxime a raíz de la STEDH «Sociedad Anónima del Ucieza contra España», a través de la activación de los mecanismos procesales que puedan conducir a la presentación de una cuestión de constitucionalidad. 


\section{BIBLIOGRAFIA}

Agudo Zamora, M., «Privilegio inmatriculador de la Iglesia Católica y vulneración de principios constitucionales a la luz de la STEDH «Sociedad Anónima del Ucieza contra España»», Revista Crítica de Derecho Inmobiliario, n. o 751, 2015.

- (Coord.), El Estatuto de Autonomía de Andalucía de 2007, Centro de Estudios Andaluces, Sevilla, 2007.

Albaladejo, M., Derecho Civil. III. Bienes, Edisofer, Madrid, 2003, 10. a edición.

Baena Alcantara, M.D., La Mezquita-Catedral de Córdoba. Francisco Baena, 1986.

Balaguer Callejón, F. y otros, El nuevo Estatuto de Andalucía. Tecnos, Madrid, 2007.

BALlARÍn HERNÁNDEZ, R., «Rectificaciones constitucionales a la vigencia actual de la certificación de dominio público como medio inmatriculador», Revista Crítica de Derecho Inmobiliario Registral, núm. 563, 1984.

Boneti PÉREZ, J., «El problema de la efectividad interna de las sentencias del Tribunal Europeo de Derechos Humanos», Revista jurídica de Catalunya, Vol. 92, n. ${ }^{\circ} 1,1993$.

Cruz Arcos, E., «La Ley 14/2007, de 14 de noviembre, de Patrimonio Histórico de Andalucía: principales contenidos e innovaciones», Patrimonio cultural y derecho, núm. 14, 2010.

De La Haza DíAz, P., «Inmatriculación de bienes de la Iglesia mediante certificación expedida por el Diocesano», Revista Crítica de derecho inmobiliario, año 71, núm. 630, 1995.

FERnÁNDEZ-Coronado GonzÁlez, A., «Posibilidades de un sistema supranacional de Derecho Eclesiástico en el marco de la Unión Europea», La Armonización Legislativa de la Unión Europea, C.E.S.S.J. Ramón Carande, II, Madrid, 2000.

García García, J.M., Código de Legislación Hipotecaria y del Registro Mercantil,

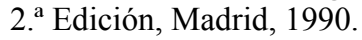

Lacruz Berdejo, J.L., Sancho Rebullida, F. de A., Luna Serrano, A., Delgado Echeverría, J., Rivero Hernández, F., y Rams Albesa, J., Elementos de Derecho Civil. III bis. Derecho Inmobiliario Registral, Dykinson, Madrid, 2001.

LiÑÁN Nogueras, D., «Los efectos de las sentencias del Tribunal Europeo de Derechos Humanos y Derecho Español», Revista Española de Derecho Internacional, XXXVII, 1985.

LlamaZARES FERNÁNDEZ, D., «Principios, técnicas y modelos de relación entre Estado y Grupos Ideológicos religiosos (Confesiones Religiosas) y no religiosos», en Revista de Estudios Políticos, núm. 88, Abril-junio de 1995, Centro de Estudios Constitucionales, Madrid, 1995.

— Derecho Eclesiástico del Estado. Derecho de la libertad de conciencia, Servicio de Publicaciones de la Universidad Complutense de Madrid, Madrid, 1991, 2. ${ }^{a}$ Edición.

«Actitud dela España democrática ante la Iglesia», en Iglesia Católica y regímenes autoritarios y democráticos (experiencia española e italiana), Madrid, 1987. 
Llamazares Fernández, D. y SuÁrez Pertierra G., «El fenómeno religioso en la Constitución Española», Revista de la Facultad de Derecho de la Universidad Complutense, núm. 61, Madrid, 1980.

LóPez Reche, G., «La Ley Andaluza de Patrimonio Histórico: novedades significativas», en López Guzman, R.J. (Coord.), Patrimonio histórico: retos, miradas, asociaciones e industrias culturales, 2010.

MAluquer De Motes Bonet, C.J., «Titularidad de los montes vecinales y constitucionalidad o no del artículo 206 de la Ley Hipotecaria por lo que toca a los bienes de la Iglesia Católica. Comentario a la Sentencia del Tribunal Supremo (Sala 1.a) de 18 de noviembre de 1996», Revista de Derecho Privado, Febrero de 1993.

Martínez de Carvajal, I., «La Ley del Patrimonio Histórico de Andalucía (2007): Catalogación y descontaminación. Nuevos retos; viejos retos», en LóPEZ GuZMAN, R.J. (Coord.), Patrimonio histórico: retos, miradas, asociaciones e industrias culturales, 2010.

—LLa Ley del Patrimonio Histórico Andaluz (2007) y el Planeamiento Urbanístico» en E-rph: Revista electrónica de Patrimonio Histórico, núm. 3, 2008.

Milione Fugali, C., El derecho a la tutela judicial efectiva en la Jurisprudencia del Tribunal Europeo de Derechos Humanos, Ed. Tirant lo Blanch, Valencia, 2015.

Muñoz Machado, S. y Rebollo Puig, M. (Coords.), Comentarios al Estatuto de Autonomía para Andalucía, Thomson-Civitas, Navarra, 2008.

Nieto Cumplido, M., La Catedral de Córdoba, Cajasur Publicaciones, Córdoba, 1998.

Peña Bernaldo de Quirós, M., Derechos Reales y Derecho Hipotecario. Tomo II. Derechos reales de garantía. Registro de la Propiedad, Centro de Estudios Registrales, Madrid, 1999.

Porras nadales, A. y Agudo Zamora, M., «Discurso y estrategia en la política cultural de la Junta de Andalucía», Constitución y Cultura. Retos del Derecho Constitucional en el Siglo XXI, Tirant Monografías, Valencia, 2005.

PRIETO SANCHís, L., «Principios constitucionales del Derecho Eclesiástico Español», en VV.AA., Curso de Derecho Eclesiástico,Servicio de Publicaciones de la U.C.M., Madrid, 1991.

Rodríguez Blanco, M., «Las certificaciones de dominio de la Iglesia Católica. Análisis del artículo 206 de la Ley Hipotecaria», Revista jurídica del Notariado, núm. 34, Abril-Junio de 2000.

RodríGuez Ramos, A.M., «Nulidad de la inmatriculación de la Mezquita-Catedral» (consultado el 26-11-2014 a las 19.00 hs en <http://laicismo.org/detalle.php?tg= $1569 \& p g=1 \& p k=32693 \# p p a l>$ )

SÁIZ ARNAIZ, A., La apertura constitucional al Derecho internacional y europeo de los derechos humanos. El art 10.2 de la Constitución Española, Consejo General del Poder Judicial, Madrid, 1999.

Terol Becerra, M. (Coord.), La reforma del Estatuto de Autonomía para Andalucia: pareceres, Instituto Andaluz de Administración Pública, Sevilla, 2007.

_ La reforma del Estatuto de Autonomía para Andalucía: posibilidades y límites, Instituto Andaluz de Administración Pública, Sevilla, 2005.

- El Estado autonómico «in fieri». La Reforma de los Estatutos de Autonomía, IAAP, Sevilla, 2005. 
Torres Gutiérrez, A., «A propósito de la reforma del Reglamento Hipotecario por el Real Decreto 1867/1998, de 4 de septiembre, en materia de registro de los bienes inmuebles de titularidad eclesiástica», Boletín de la Sociedad Española de Ciencias de las Religiones, núm. 9, 1998.

- «Estudio crítico de los privilegios de la Iglesia Católica en materia de inmatriculación de bienes», en VV.AA., Escándalo monumental. La privatización de las iglesias, ermitas, casas, tierras y otros bienes públicos en Navarra, Altaffaylla Kultur Aldea, Tafalla, 2009.

- En torno a la inconstitucionalidad del proceso inmatriculador de fincas de los artículos 206 de la Ley Hipotecaria y 304 de su Reglamento, consultado en <http://laicismo.org>, (consultado el 12-11-2014, a las 17.30 hs.)

- «Comentario a la Sentencia del Tribunal Constitucional 340/1993, de 16 de noviembre», (por error aparece impresa la fecha 13 de mayo), en MARTínEz ToRRÓN, J., (Coord.), La libertad religiosa y de conciencia ante la justicia constitucional. Actas del VIII Congreso Internacional de Derecho Eclesiástico del Estado, Comares, Granada, 1998.

VILADRICH, P.J., y FERRER ORTIZ, J., «Los principios informadores del Derecho Eclesiástico Español», en VV.AA., Derecho Eclesiástico del Estado Español, EUNSA, Pamplona, 1996, 4. ${ }^{\text {E Edición. }}$

VV.AA., Reforma del Estatuto de Autonomía para Andalucía, Parlamento de Andalucía, Centro de Publicaciones no Oficiales, Sevilla, 2005.

TITLE: Registration of the Cordoba's Mosque-Cathedral: Protection of heritage and constitutional relevance.

RESUMEN: En este trabajo, partiendo del caso de la Mezquita-Catedral de Córdoba se exponen sucintamente los argumentos en los que basar una posible inconstitucionalidad del artículo 206 de la Ley Hipotecaria, referidos a la violación de los principios constitucionales de aconfesionalidad del Estado y de igualdad, con referencias a la Sentencia del Tribunal Europeo de Derechos Humanos «Sociedad Anónima del Ucieza contra España», que tiene una relevancia especifica para el objeto de nuestro estudio. Finalmente se analiza el deber de tutela del patrimonio histórico y cultural de la Comunidad Autónoma de Andalucía y el posible uso de la cuestión de constitucionalidad como vía de actuación de la Junta de Andalucía en relación a la inscripción registral de la Mezquita-Catedral.

PALABRAS CLAVE: Mezquita-catedral; inmatriculación; Iglesia católica; igualdad; aconfesionalidad; inconstitucionalidad; protección del patrimonio.

ABSTRACT: In this paper, based on the case of the Mosque-Cathedral of Cordova, we outlines the arguments on which to base a possible unconstitutionality of Article 206 of the Mortgage Act, concerning the violation of the constitutional principles of secularism and equality, with references to Judgment of the European Court of Human Rights «SA of Ucieza against 
Spain», which has a specific relevance to the subject of our study. Finally, we analyze the duty of protection of historical and cultural heritage of Andalusia and the possible use of the "cuestion de constitucionalidad» as a means of action of the Junta de Andalucia in relation to the registration of the Mosque-Cathedral.

KEYWORDS: Mosque-cathedral; registration; Catholic Church; equality; secularism; unconstitutionality; protection of heritage.

RECIBIDO: 20.11.2015

ACEPTADO: 09.11.2015 